\title{
テーパー杭を用いた小規模建築 物基礎の鉛直載荷試験
}

\section{VERTICAL LOADING TEST OF SMALL BUILDING FOUNDATIONS USING TAPERED PILE}

\author{
佐藤 隆 一 $* 1$ \\ 安達俊夫 一 $* 2$ \\ キーワード : \\ 小規模建築物, 基礎工法, テーパー杭, 実大実験, 長期載荷, \\ 急速載荷 \\ 塩沢伸明
}

Keywords:

Small building, Foundation practice, Tapered pile, Long term loading, Rapid loading
Takashi SATOU Toshio ADACHI

Long term loading test of the decreasing effect of settlement about small building foundations using tapered pile were conducted. We used basis reinforced with tapered pile and straight pile. This paper presents the outline of the loading tests and results of the tests and so on. From the studies, analyzes about settlement of foundation and the load distribution ratio of base slab and pile.
1.はじめに

軟弱地盤に於ける小規模建築物の基礎工法として小口径鋼管杭を 用いたいわゆる杭工法やセメント系固化材を用いた地盤補強工法が ある。筆者等は小規模建築物を対象とした基䃈工法として、支持力 特性に優位性のあるテーパー杭を用いた摩擦杭工法を研究 1) 2)して きた。

テーパー杭の支持力性能に関しては冨永等の室内実験を基にした 研究により、ストレート杭に比べ優位性があることが言われている。

また冨永等によりローム地盤における単杭の載荷試験 ${ }^{3)} に よ り 、$ 支持力特性等に関寸る研究もされている。また筆者等の研究 ${ }^{2)}$ では 軟弱地盤を含む 6 現場での単杭の載荷試験により、テーパー杭がス トレート杭に比べ支持力に関する優位性があることも確認している。 しかしながら、これらの研究並びに載荷試験は、単杭としてのテ 一パー杭の支持力機構に関するものであり、テーパー杭を小規模建 築物等の基礎工法として実用化するためにはテーパー杭と基礎スラ ブとの荷重分担による沈下抑制効果に関する検証をすることが必要 であると考える。

そこで、テーパー杭とストレート杭により補強された基礎試験体 およびベタ基礎試験体に対し、長期にわたる鉛直載荷実験を行い、 それらの沈下抑制効果について確認実験を行なう事とした。載荷荷 重としては、一般的な木造 2 階建ての接地圧 (約 $15 \mathrm{k} \mathrm{N} / \mathrm{m}^{2}$ )、 $\mathrm{RC}$ 造 3 階建の接地圧（約 $60 \mathrm{k} \mathrm{N} / \mathrm{m}^{2}$ ) を想定した。

本論文は、その鉛直載荷試験結果から得られたデータから、テー パー杭およびストレート杭により補強された基礎スラブのパイルド ラフト効果について、沈下計測および杭と基礎スラブの荷重分担等 に関する検討結果を報告するものである。

\section{2. 地盤概要}

図 1 に GL- $47 \mathrm{~m}$ までの当該試験場の地層構成を、図 2 に GL-12 ま
での柱状図及び試験体概要を示す。
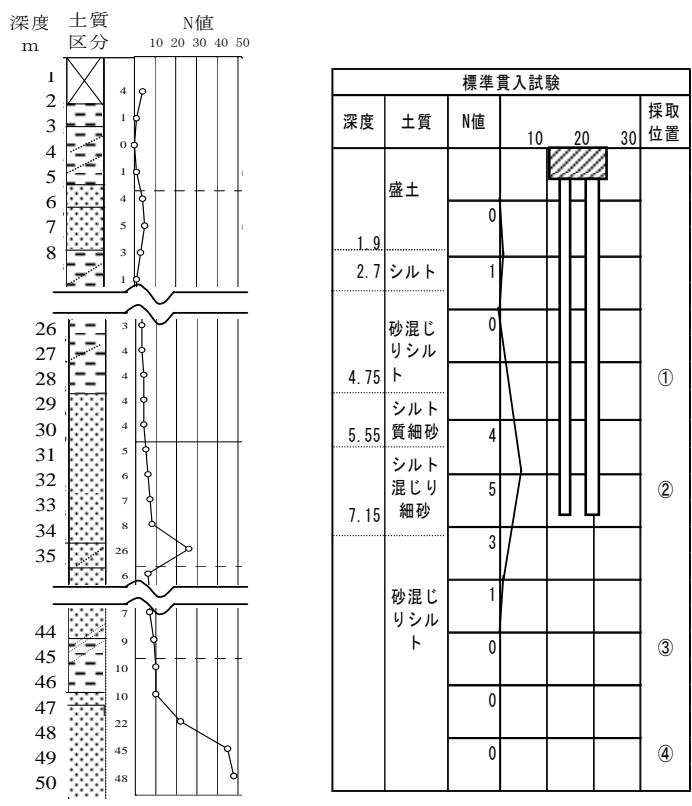

図 1 地層構成

図 $2 \mathrm{GL}-12 \mathrm{~m}$ までの柱状図及び試験体概要

試験場は埼玉県平野部の沖積低地に位置し、第四紀更新世堆積物 である洪積層の上位に第四紀完新世堆積物である沖積層が分布する。

$\mathrm{GL}-1.9 \mathrm{~m}$ までが $\mathrm{N}$ 值 $0 \sim 4$ のガラ混じり盛土、GL-1.9m〜 $4.75 \mathrm{~m}$ までが N值 0〜1 のシルトおよび砂混じりシルト、GL $-4.75 \mathrm{~m} \sim 7.15$ $\mathrm{m}$ までが $\mathrm{N}$ 值 4〜5 のシルト質細砂、シルト混じり細砂、GL-7. $15 \mathrm{~m}$ 以深は GL-47m以深の $\mathrm{N}$ 值 20 以上の砂層まで $\mathrm{N}$ 值 $0 \sim 1$ の砂混じり シルトあるいは $\mathrm{N}$ 值 4 程度のシルト層が連続している軟弱地盤であ る。表 1 に土質試験の結果を示す。なお、圧密試験に関しては、

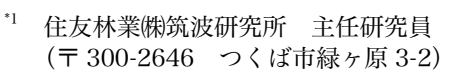

日本大学理工学部 教授・工博

\footnotetext{
Engineer, Sumitomo Forestry Co., Ltd.

*2 Prof., College of Science \& Technology, Nihon Univ., Dr. Eng.
} 
GL-5. 55m〜7. 15mのシルト混じり砂質土層を除く各層で行った。

表 1 土質試験結果

\begin{tabular}{|c|c|c|c|c|c|c|}
\hline \multicolumn{7}{|c|}{ 土質試験結果 } \\
\hline \multicolumn{3}{|r|}{ 資料番号 } & (1) & (2) & (3) & (4) \\
\hline \multicolumn{3}{|r|}{ 深さ (m) } & $4.00 \sim$ & $6.00 \sim$ & $\begin{array}{c}9.00 \sim \\
9.80\end{array}$ & $11.00 \sim$ \\
\hline \multicolumn{3}{|r|}{ 土質 } & シルト & 細砂 & シルト & $\begin{array}{l}\text { シル卜 } \\
\end{array}$ \\
\hline \multirow{5}{*}{ 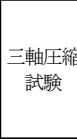 } & & 試験条件 & $\mathrm{UU}$ & $\mathrm{CD}$ & $\mathrm{UU}$ & $\mathrm{UU}$ \\
\hline & & $\mathrm{Cu}, \mathrm{Cd}\left(\mathrm{kN} / \mathrm{m}^{2}\right)$ & 39.9 & 8.6 & 38.8 & 46.2 \\
\hline & & $\phi \mathrm{u}, \phi \mathrm{d}\left(^{\circ}\right)$ & 8.52 & 39.1 & 0 & 0 \\
\hline & & (rad) & 0.1487 & 0.682 & 0 & 0 \\
\hline & & $\tan \phi$ & 0.15 & 0.812 & 0 & 0 \\
\hline \multirow{6}{*}{ 圧密試験 } & 初 & 含水比 $W^{\prime} O \%$ & 40.7 & & 53.2 & 57.4 \\
\hline & 期 & 間隙比 $e_{0}$ & 1.182 & & 1.444 & 1.569 \\
\hline & & 湿潤密度 $\rho, \mathrm{g} / \mathrm{cm}^{3}$ & 1.741 & & 1.674 & 1.632 \\
\hline & & 飽和度 $S_{r 0} \%$ & 92.9 & & 98.3 & 97.4 \\
\hline & 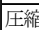 & 指数 $C c$ & 0.35 & & 0.51 & 0.6 \\
\hline & 圧密 & 降伏応力 $P_{C} \mathrm{kN} / \mathrm{m}^{2}$ & 241 & & 154 & 141 \\
\hline
\end{tabular}

試験場の表層部 GL-1.9m までの盛土層はガラなどの障害物が混 入していることから、ガラなどの撤去後に基礎試験体の床付けレ心゙ ル（=GL-0.7m） までを砂を混入しながら埋め戻し転圧を行った。 埋め戻し後に試験体の設置位置周辺の地盤について、基礎試験体 底版レベル (GL-0.7m) から GL-1.9mまでの部分に対し、スウェー デン式サウンディング試験（以後 SWS とする）を行なった。表 2 に 埋め戻し部 SWS 試験結果とヤング率を、表 3 に $\mathrm{m}_{\mathrm{v}}$ 值一覧を示す。 SWS 試験結果は 6 箇所の調查データの平均值（Wsw、Nsw）とする。 埋め戻し部の地盤のヤング率及び $\mathrm{m}_{\mathrm{v}}$ 值を下式 ${ }^{4)}$ を用いて算出した。

$E=85 N s w+5000 W s w \cdots$. (1)

$m_{v}=\frac{1}{E} \times \frac{2}{3} \cdots \cdots \cdot(2)$

$E:$ 地盤のヤング率 $\left(\mathrm{kN} / \mathrm{m}^{2}\right)$

$m_{V}:$ 体積圧縮係数 $\left(\mathrm{m}^{2} / \mathrm{kN}\right)$

Wsw : 荷重 $(\mathrm{kN})$

Nsw：1mあたりの半回転数

表 2 埋め戻し部 SWS 試験結果とヤング率

\begin{tabular}{|c|c|c|c|c|}
\hline \multirow{2}{*}{$\begin{array}{c}\text { 深度 } \\
(\mathrm{m})\end{array}$} & \multicolumn{2}{|c|}{ SWSデータ平均 } & \multicolumn{2}{|c|}{ ヤング率 } \\
\hline & Wsw $(\mathrm{kN})$ & Nsw & $\mathrm{E}\left(\mathrm{kN} / \mathrm{m}^{2}\right)$ & 平均 \\
\hline 0.25 & 1.00 & 0 & 5000 & \multirow{5}{*}{5135} \\
\hline 0.50 & 1.00 & 26.67 & 7267 & \\
\hline 0.75 & 0.88 & 9.33 & 5193 & \\
\hline 1.00 & 0.83 & 1.33 & 4263 & \\
\hline 1.25 & 0.79 & 0 & 3950 & \\
\hline
\end{tabular}

表 $3 \quad \mathrm{~m}_{\mathrm{v}}$ 値一覧

\begin{tabular}{|l|l|c|}
\hline 梁度 $(\mathrm{m})$ & \multicolumn{1}{|c|}{ 土質 } & $\mathrm{m}_{\mathrm{v}}$ \\
\hline $0.7 \sim 1.9$ & 盛土 (埋め戻し部 $)$ & $1.298 \mathrm{E}-04$ \\
\hline $1.9 \sim 4.75$ & シルト層 & $3.000 \mathrm{E}-04$ \\
\hline $4.75 \sim 7.15$ & シルト質細砂層 & $1.190 \mathrm{E}-04$ \\
\hline $7.15 \mathrm{~m}$ 以深 & シルト層 & $3.200 \mathrm{E}-04$ \\
\hline
\end{tabular}

\section{3. 実験概要}

\section{1 基礎試験体}

実験に用いた試験体は 3 種類とし、テーパー杭を用いた基礎試験 体をNo. 1、ストレート杭を用いた基礎試験体をNo. 2、ベタ基礎試験 体をNo. 3 とした。以下に概要を示す。

試験体 No. 1 : テーパー杭を用い、杭間隔を $1820 \mathrm{~mm}$ で 4 本設置 試験体 No. 2 : ストレート杭を用い、杭間隔を $1820 \mathrm{~mm}$ で 4 本設置 試験体 No. 3 : ベタ基礎

基礎および杭の諸元を以下に示す。図 2 に示すように杭先端は $\mathrm{GL}-7 \mathrm{~m}$ 付近の $\mathrm{N}$ 值 3〜 5 のシルト質細砂層に位置する。

基礎スラブ : 幅 $2.2 \mathrm{~m} \times 2.2 \mathrm{~m}$ 、厚さ $0.7 \mathrm{~m} 、 \mathrm{RC}$ 造 ストレート杭: 一般構造用炭素鋼管（JIS G 3444、STK400） $\mathrm{t}=4.5 \mathrm{~mm}$ テーパー杭：一般構造用炭素鋼管を加工、勾配 $1 / 150 \quad \mathrm{t}=4.5 \mathrm{~mm}$ 表 4 に試験体の仕様および杭体のひずみゲージ位置を示す。杭頭 A 部については埋め戻し転圧部分に位置し、軸力分担などの検討に 有効な杭体部分を B 部とした。試験に用いる杭の先端部はストレー ト杭、テーパー杭両者とも閉塞とした。

\section{2 試験体配置および計測位置}

計測項目は試験体の沈下量および杭の軸ひずみ值である。載荷開 始以後の試験体の沈下量および杭の軸ひずみ值に関しては自動計測 としたが、コンクリート打設から硬化までの期間についての基礎試 験体の沈下量の測定は、敷地内に GL- $47 \mathrm{~m}$ 以深を先端の位置とした 2

表 4 試験体仕様および杭体ひずみ測定位置

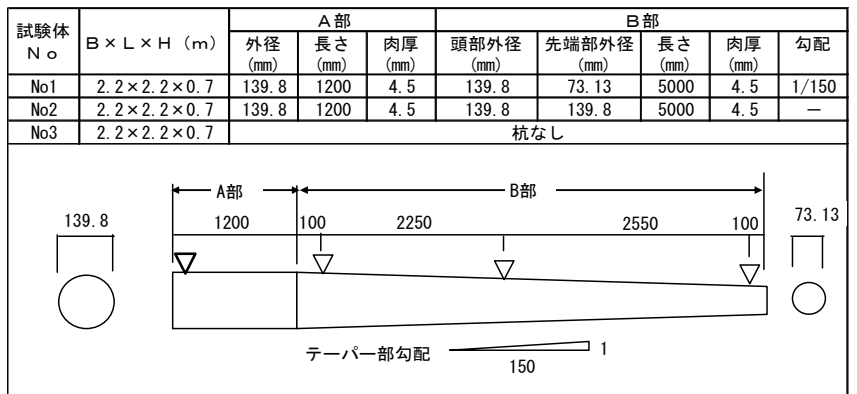

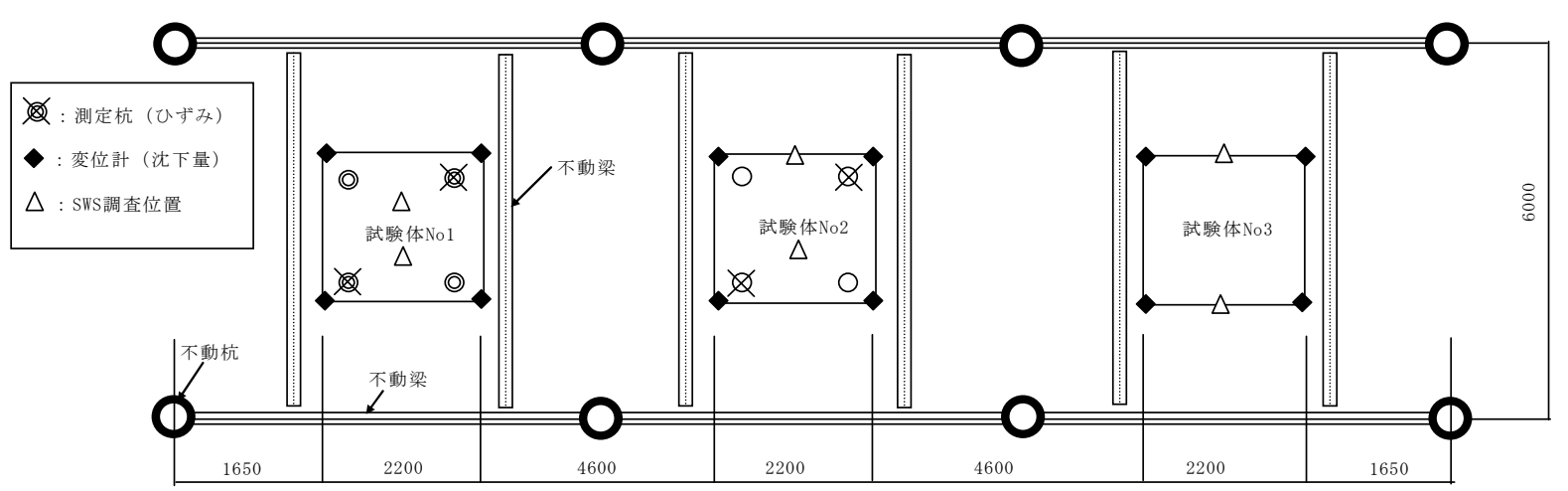

図 3 試験体配置および計測位置図 $(\mathrm{mm})$ 
重管の不動杭を設置し、光学計測計による目視計測で行った。図 3 に各試験体の計測内容および計測位置を示す。

図 4 に基礎試験体の地層構成と断面概要図ならびに杭の軸ひずみ 計測位置を示す。ひずみ測定位置は地層構成に従う事とし、第 2 ゲ ージ-第 3 ゲージの間を区間 1 、第 3 ゲージ-第 4 ゲージの間を区間 2 とした。

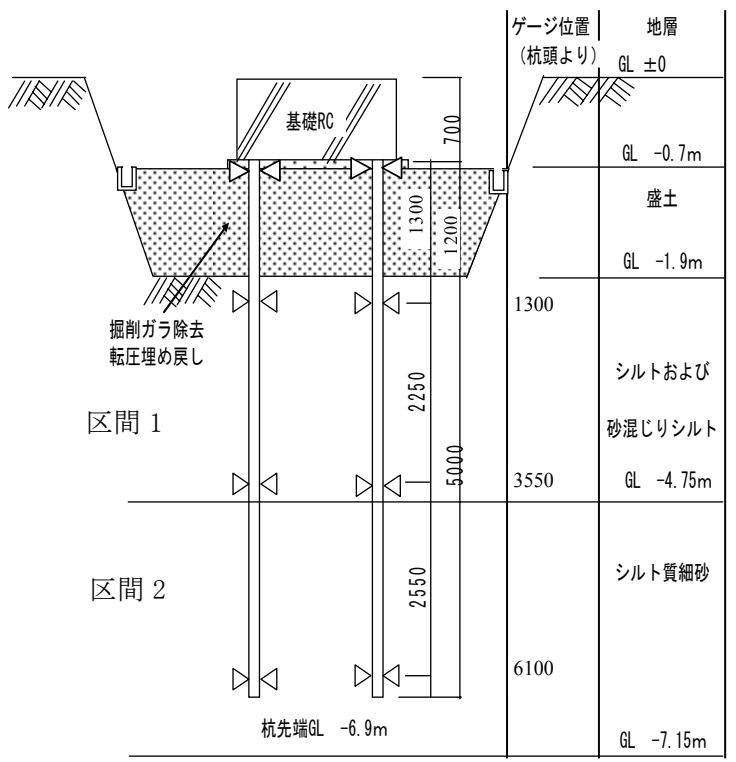

図 4 試験体断面概要図

\section{3 載荷方法}

載荷荷重は、 $\mathrm{RC}$ 造 3 階建て程度の建物荷重を最大とした計画とし た。なお、放置期間は後述する $\mathrm{m}_{\mathrm{v}}$ 法による沈下計算の結果を基に 決定する。各載荷段階を以下のようにし、各 STEP の荷重度及び放置 期間を図 5 に示す。

STEP1：基礎躯体作成～第一次載荷開始前（荷重度 $16.1 \mathrm{kN} / \mathrm{m}^{2}$ )

STEP2 : 第一次載荷期間 (荷重度 $50 \mathrm{kN} / \mathrm{m}^{2}$ )

STEP3 : 第二次載荷期間 (荷重度 $75 \mathrm{kN} / \mathrm{m}^{2}$ )

STEP4：急速載荷試験

STEP2 以降は 1 枚約 $5 \mathrm{kN}$ の鋼板を用いて載荷を行うこととし、載 荷方法については以下の要領とした。

STEP2：6段階載荷、荷重保持時間 30 分とした。

STEP3:STEP2 の載荷状態に対し 3 段階で載荷鋼板を増加し、荷重 保持時間は 30 分とした。

STEP4: 各試験体の載荷用鋼板を撤去した状態に対し 5 段階の載荷 とし、荷重保持時間を 30 分とした。

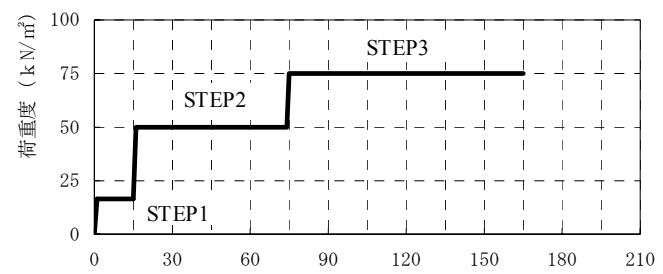

図 5 各 STEP の載荷計画

\section{3. $4 \mathrm{~m}_{\mathrm{v}}$ 法による沈下量の予測}

放置期間の設定に当たり、 $\mathrm{m}$ v 法により沈下量の算定を行なった。
算定の対象は試験体 No. 3 のベタ基礎とした。沈下量の算出に当た り、埋め戻し部分については（1）式を、GL-1.9m 以深地層に関して は圧密試験結果から求めた $\mathrm{m}_{\mathrm{v}}$ を利用した。埋め戻し部分のヤング 率は表 2 の平均ヤング率 $\mathrm{E}=5135 \mathrm{kN} / \mathrm{m}^{2}$ を用いた。沈下量の算定は (3) 式を用い、STEP3 における試験体 No3 の圧密沈下分布を表 5 に、及 び各 STEP の算定結果を表 6 に示す。

$$
\begin{aligned}
& S=\Sigma m_{v} \cdot \Delta \sigma_{i z} \cdot \Delta H_{i} \cdots \cdots \cdot(3) \\
& S: \text { 压密沈下量 }(\mathrm{m}) \quad \Delta \sigma: \text { 地中増加応力 }\left(\mathrm{kN} / \mathrm{m}^{2}\right) \\
& \Delta H: \text { 圧密対象層厚 }(\mathrm{m})
\end{aligned}
$$

各地層の沈下量の算定位置は各層の中間深度とし、各層の中間深 度における地中増加応力を基に算出した。なお、圧密の影響範囲は シルト層の連続する $\mathrm{GL} \pm 0 \mathrm{~m} \sim \mathrm{GL}-28 \mathrm{~m}$ までとした。

\section{表 5 試験体 No3 の圧密沈下量分布}

\begin{tabular}{|r|r|r|r|c|r|}
\hline $\mathrm{D}(\mathrm{m})$ & 算定位置 $(\mathrm{m})$ & \multicolumn{1}{c|}{$\Delta \mathrm{H}(\mathrm{m})$} & $\sigma^{\prime} 2 \mathrm{zi}$ & $\mathrm{mv}$ & 沈下量 $\mathrm{S}(\mathrm{mm})$ \\
\hline 0.7 & - & - & - & - & - \\
\hline 1.9 & 1.3 & 1.2 & 68.533 & $1.2983 \mathrm{E}-04$ & 10.68 \\
\hline 4.75 & 3.325 & 2.85 & 19.440 & $3.0000 \mathrm{E}-04$ & 16.62 \\
\hline 7.15 & 5.95 & 2.4 & 5.862 & $1.1905 \mathrm{E}-04$ & 1.67 \\
\hline 28 & 17.575 & 20.85 & 0.506 & $3.2000 \mathrm{E}-04$ & 3.38 \\
\hline \multicolumn{7}{|c|}{ 総沈下量 } & 32.35 \\
\hline
\end{tabular}

表 6 載荷 STEP の沈下量一覧

\begin{tabular}{|c|c|c|}
\hline 載荷STEP & $\begin{array}{c}\text { 載荷荷重 } \\
\left(\mathrm{kN} / \mathrm{m}^{2}\right)\end{array}$ & $\begin{array}{c}\text { 沈下量 } \mathrm{S} \\
(\mathrm{mm})\end{array}$ \\
\hline STEP1 & 16.1 & 6.94 \\
\hline STEP2 & 50.0 & 21.57 \\
\hline STEP3 & 75.0 & 32.35 \\
\hline
\end{tabular}

\section{4. 実験結果}

載荷試験の状況を写真 1 に示す。

沈下測定は基礎スラブ躯体作成時から開始し目視計測および自動 計測とした。以下、各 STEP の載荷試験の結果を述べる。

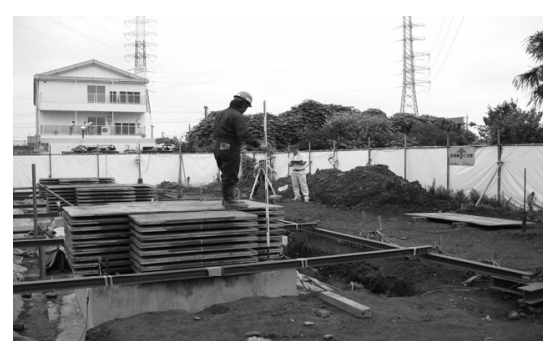

写真 $1 \quad$ STEP2 の沈下量測定状況

\section{1 長期載荷試験（STEP1～STEP3）}

\subsection{1 沈下量一経過日数}

(1) STEP 1

STEP1 は基礎スラブのコンクリート打設後の硬化のための養生期 間である。沈下量測定は、試験体 No. 1 及び No. 2 については杭頭部 にレベル測定用の治具を、試験体 No. 3 は基礎スラブ下にレベル測定 用治具をそれぞれ設置し、目視測定とした。図 6 に沈下量と経過 日数の関係を示す。

図 6 から STEP1 の最終沈下量は、試験体 No. 1 が $0.75 \mathrm{~mm}$ 、試験体 No. 2 は $2.5 \mathrm{~mm}$ 、試験体 No. 3 は $5.75 \mathrm{~mm}$ となった。 


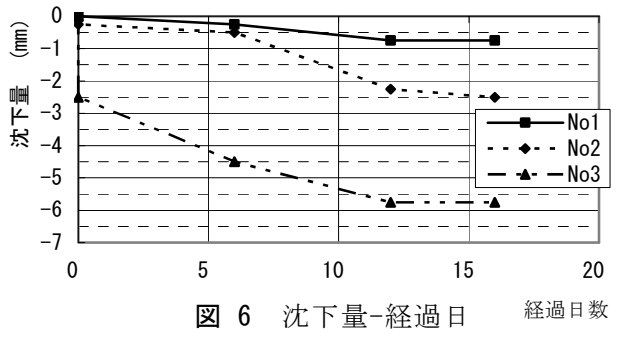

試験体 No. 3 はコンクリート打設日に約 $2.5 \mathrm{~mm}$ の沈下量を示し、そ の直後より沈下量が漸増する傾向を示したが、試験体 No. 1 ならびに 試験体 No. 2 は約 7 日後までは沈下量が小さな值を示し、以後沈下量 の漸増が見られることがわかる。

STEP1 の載荷荷重は約 $16 \mathrm{kN} / \mathrm{m}^{2}$ であり、一般的な木造 2 階建ての基 礎下接地圧に相当するが、短期間の沈下量の比較ではあるが、基礎 試験体 No. 1 は試験体 No. 2 に比べ約 $1 / 3$ の沈下量であり、テーパー 杭を用いた基礎の沈下抑止に関する優位性を示すことが確認できた。

(2) STEP2

図 7, 図 8, 図 9 は各試験体の沈下量と経過日数の関係を示したも のである。いずれのグラフも沈下量の測定結果を実線で、双曲線に よる近似曲線を破線で示したものである。なお各図は STEP1の最終 沈下量をそれぞれ載荷日の初期值として加算したものとした。

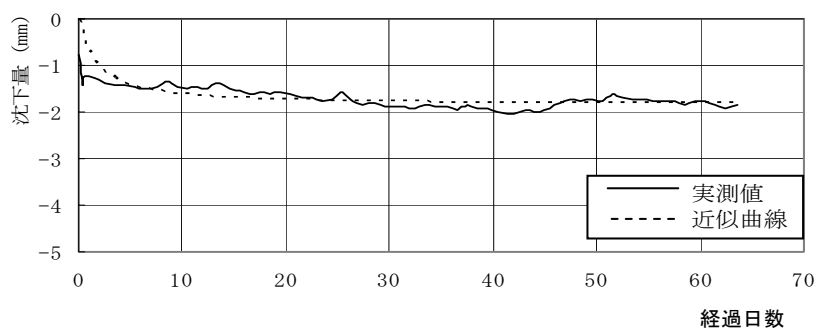

図 7 No. 1 沈下量と経過日数の関係

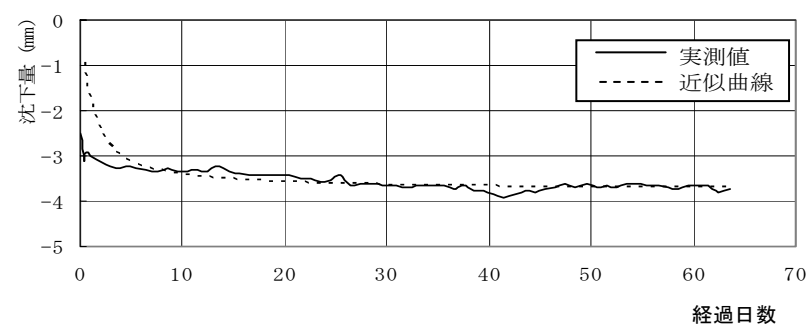

図 8 No. 2 沈下量と経過日数の関係

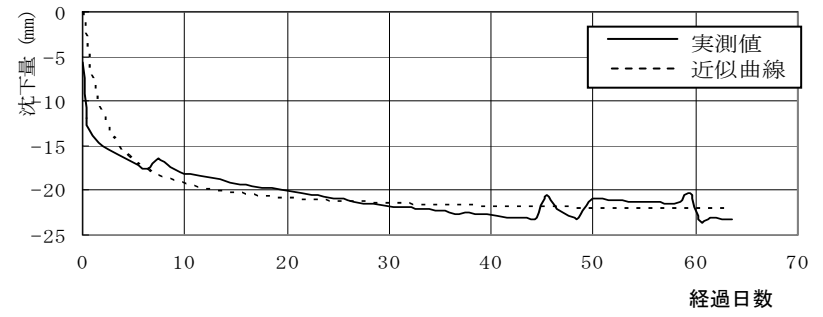

図 9 No. 3 沈下量と経過日数の関係

各試験体の実測沈下量および双曲線法による最終の予測沈下量は 以下の結果の通りとなった。

試験体 No. 1 : 実測值 $\mathrm{S}=1.87 \mathrm{~mm}$ （最終沈下量の近似值 $1.87 \mathrm{~mm}$ ) 試験体 No. 2 : 実測值 $\mathrm{S}=3.81 \mathrm{~mm}$ （最終沈下量の近似值 $3.76 \mathrm{~mm}$ ) 試験体 No. 3 : 実測值 $\mathrm{S}=23.3 \mathrm{~mm}$ （最終沈下量の近似值 $\mathrm{S}=22.81 \mathrm{~mm}$ ) いずれの試験体も載荷後約 60 日で最終沈下の近似值と同等な沈
下量の測定結果になった。また試験体 No. 3 については、表 5 に示す $\mathrm{m}_{\mathrm{v}}$ 法による沈下予測の計算值 $\mathrm{S}=21.57 \mathrm{~mm}$ とおおむね良い対応を示 す結果となった。また、試験体の沈下量比較では試験体 No. $1<$ 試験 体 No. $2<$ 試験体 No. 3 の順で大きな沈下量を示す結果となった。

沈下量の推移に関しては、試験体 No. 1 は載荷直後に最終沈下量の $77 \%$ の沈下量を、約 20 日後に $90 \%$ の沈下量を示した。試験体 No. 2 は載荷直後に最終沈下量の $83 \%$ 程度の沈下量を、約 14 日後に $90 \%$ の沈下量を示した。試験体 No. 3 は載荷直後に約 $50 \%$ 、約 14 日後に 最終沈下量の $80 \%$ の沈下量となり、以後沈下量は漸増した。

\section{(3) STEP1 STEP3}

STEP1 から STEP3 の沈下量と経過日数の関係を図 10 に示す。各試 験体の最終沈下量は以下のようになった.

試験体 No. $1: \mathrm{S}=3.89 \mathrm{~mm}$

試験体 No. $2: S=5.83 \mathrm{~mm}$

試験体 No. $3: S=40.2 \mathrm{~mm}$

試験体 No. 3 については表 6 の $\mathrm{m}_{\mathrm{V}}$ 法による沈下予測の $\mathrm{S}=32.35 \mathrm{~mm}$ を超える結果となった。各試験体の沈下量の比較では試験体 No. $1<$ 試験体 No. 2 <試験体 No. 3 の順で大きな沈下量を示す結果となった。 沈下量の推移に関しては、試験体 No. 1 は載荷直後に最終沈下量の $69 \%$ の沈下量を、約 14 日後に $80 \%$ の沈下量を、約 60 日後に $90 \%$ の 沈下量となった。試験体 No. 2 は載荷直後に最終沈下量の $79 \%$ 程度 の沈下量を、約 30 日後に $90 \%$ の沈下量となった。試験体 No. 3 は載 荷直後に約 $72 \%$ 、約 17 日後に最終沈下量の $90 \%$ の沈下量となり、 以後沈下量が漸増する結果となった。

以上のように、杭により補強された試験体 No. 1、No. 2 の沈下量は ベタ基礎試験体 No. 3 に比心゙小さな值となった。

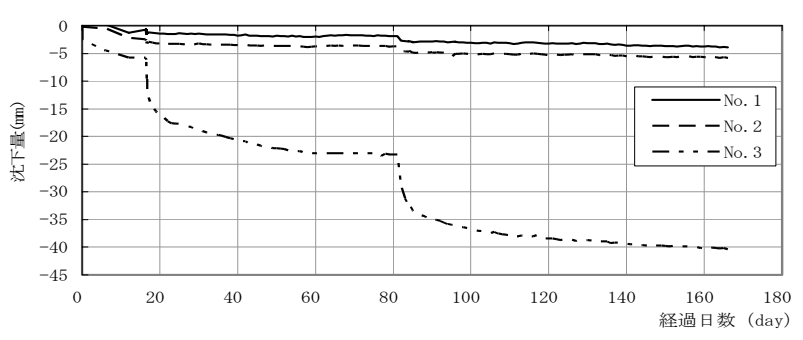

図 10 STEP1-2-3 沈下測定結果

\subsection{2 杭の軸力分布}

STEP2 と STEP3 の載荷直後における杭の軸力分布を図 11 、図 12 に示す。図 11、図 12 の $\mathrm{GL} \pm 0 \mathrm{~m}$ は GL-0.7mm の杭頭部レベル（=基 礎底盤レベル）を $\mathrm{GL} \pm 0 \mathrm{~m}$ とした深度の表記としている。測定杭の ひずみ測定值から軸力を算出したものある。両 STEP ともに杭頭部の 軸力はテーパー杭が大きい值を示したが、杭先端部の軸力はストレ 一ト杭が大きな值を示している。また、両 STEP ともに、杭先端部一 の荷重の到達率はテーパー杭で約 4\%, ストレート杭で約 $15 \%$ とな った。

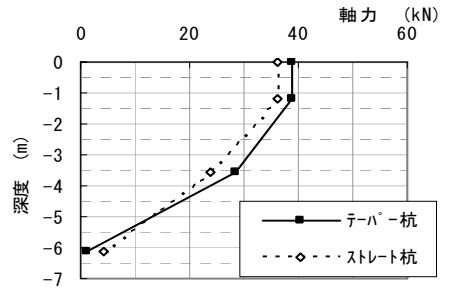

図 11 STEP2 の軸力分布

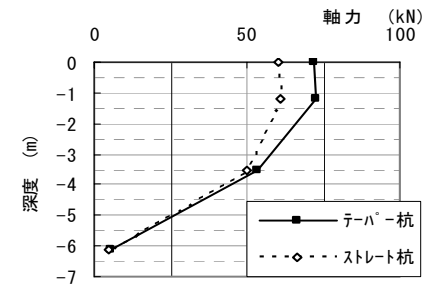

図 12 STEP3 の軸力分布 


\subsection{3 摩擦応力と経過日数の関係}

各区間の杭周面に生じた摩擦応力 $\tau$ と経過日数の関係を図 13、図 14 に示す。杭頭部は埋め戻し部分であるため、ここでは GL-1. $2 \mathrm{~m}$ 以 深のひずみ計測を行った区間 1 および区間 2 について、摩擦応力 $\tau$ の経過日数との関係を示す。

図 13、図 14 から、STEP2 から STEP3 への移行日に、試験体 N0.1 のテーパー杭ならびに試験体 No. 2 のストレート杭の杭周面の摩擦 応力 $\tau$ が上昇していることがわかる。区間 1 ならびに区間 2 の両者 とも両 STEP の放置期間については摩擦応力 $\tau$ にばらつきが見られ る結果となったが、区間 2 については摩擦応力 $\tau$ が経過日数の推移 により増加傾向を示寸傾向があることがわかる。

なお、杭周面に生じる摩擦応力 $\tau$ の比較としては、区間 1 および 区間 2 のいずれの区間も、試験体 No. 1 のテーパー杭が試験体 No. 2 のストレート杭に比べ大きな数值を示寸結果となった。

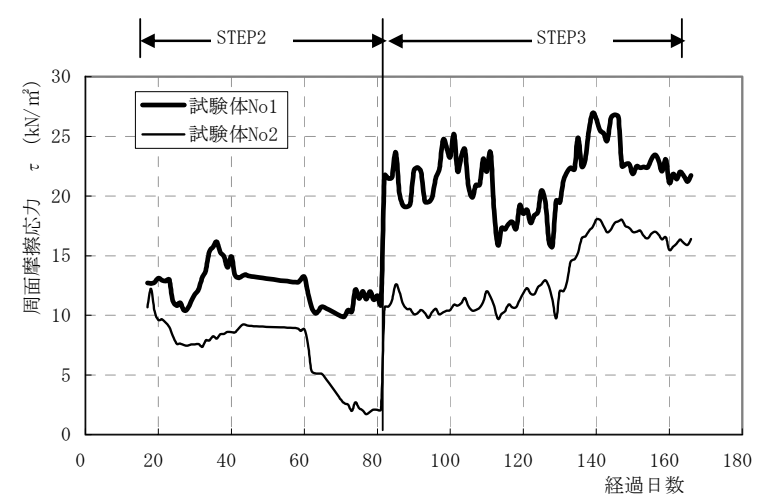

図 13 区間 1 の摩擦応力 $\tau$ と経過日数の関係

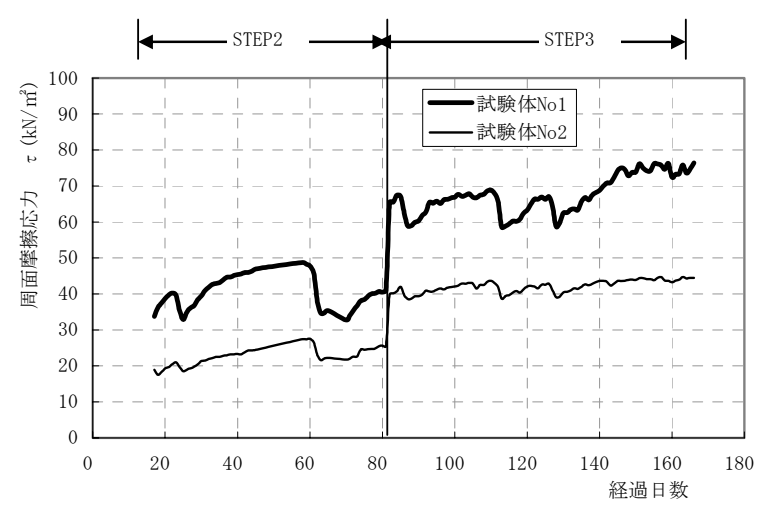

図 14 区間 2 の摩擦応力 $\tau$ と経過日数の関係

\subsection{4 荷重分担率と経過日数の関係}

STEP2 STEP3 の荷重分担率と経過日数との関係を図 15 に示す。

図は試験体 No. 1 ならびに試験体 No. 2 について、各試験体の杭頭 部のひずみ量から算出した軸力の合計を杭の負担する荷重分とし、 基礎スラブ自重分を除いた荷重（=載荷鋼板重量）で除したもので ある。

図から、ばらつきがあるものの STEP2-STEP3 を通じて、試験体 No. 1 の荷重分担率が試験体 No. 2 に比べ大きな数值を示すことがわかる。

また、荷重分担率の推移については摩擦応力 $\tau$ の推移とおおむね
良い対応を示していることが見られた。

試験体 No. 1 では STEP2 の載荷後に荷重分担率が $100 \%$ を超える值 を示した。これは基礎スラブの自重分の荷重が杭へ移行しているこ とを示していると思われる。この現象の原因としては、試験体の荷 重を基礎スラブ下の地盤支持力と杭の支持力とで分担支持するとき に、載荷直後の段階では基礎スラブ下の地盤が主に荷重分担し、そ の後、その荷重による地盤の圧密により杭一試験体荷重が移行する 事により、杭のひずみ測定開始時に初期化した基礎スラブ自重分を 含めての載荷荷重が杭へ移行したことに起因するものと推量する。

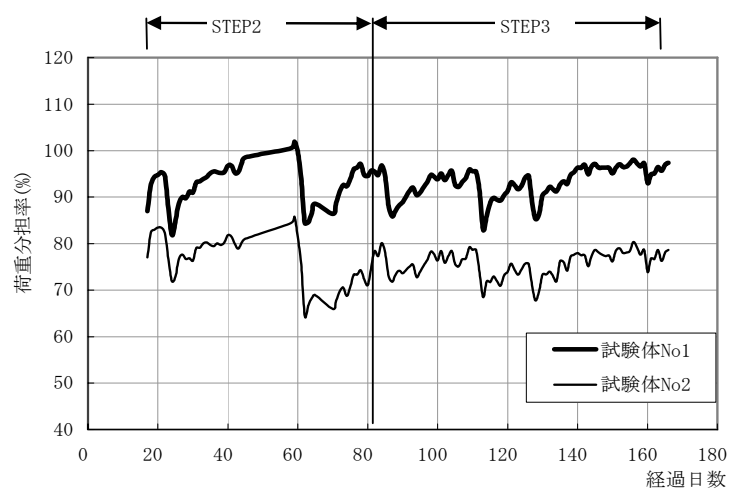

図 15 STEP2-STEP3 荷重分担率と経過日数の関係

\section{2 急速載荷試験 (STEP4)}

STEP4では急速載荷試験を行った。最終の載荷荷重は、試験体 No. 1、 No. 2 が試験体自重を含む全荷重を $135 \mathrm{k} \mathrm{N} / \mathrm{m}^{2} 、 N o .3$ が $118 \mathrm{k} \mathrm{N} / \mathrm{m}^{2}$ と した。なお、載荷荷重は長期載荷試験に用いた鋼板を用いたが、試 験開始前に全鋼板を撤去した後に変位測定を初期化し、急速載荷試 験を実施した。

\section{2.1 荷重沈下関係}

STEP4 の荷重沈下関係を図 16 に示寸。図は試験体自重を除き、載 荷した鋼板荷重と沈下量の関係を示したものである。

荷重沈下の関係は長期載荷試験の結果と同様な傾向を示寸結果と なったが、図 16 に示すように沈下量が $3 \mathrm{~mm}$ 程度の荷重初期段階での 荷重と沈下の関係は試験体 No. 1 と試験体 No. 2 は同等な值となり、 試験体 No. 3 が最も低い值を示す結果となった。

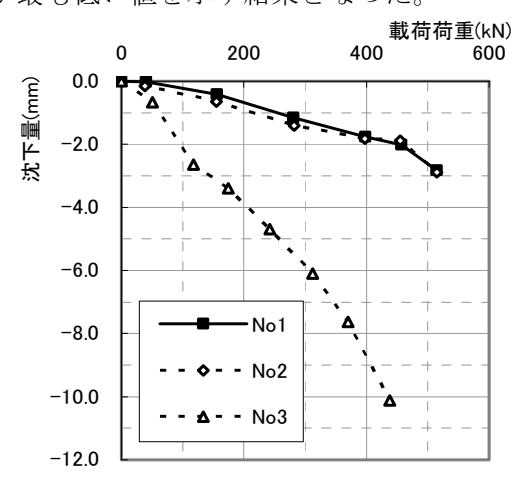

図 16 荷重沈下関係

\section{2.2 杭の軸力分布}

図 17 に杭の各載荷段階でのテーパー杭とストレート杭の軸力分 布を示す。各載荷段階ともに杭頭軸力についてはテーパー杭がスト 
レート杭より大きな值を示寸結果である。また、最終段階での杭先 端部への荷重伝達率はテーパー杭で約 6\%、ストレート杭で約 $15 \%$ となった。

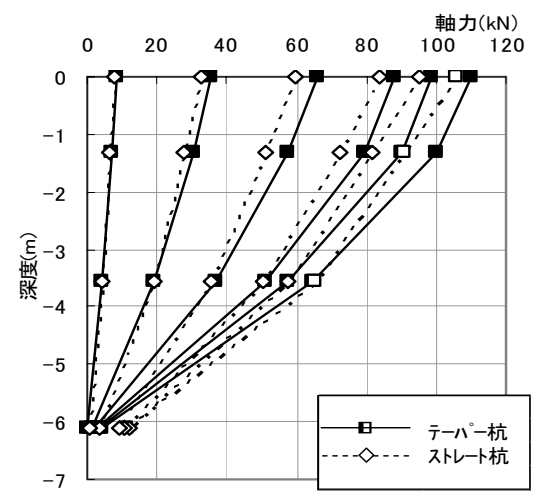

図 17 杭の軸力分布

\section{2.3 杭の荷重分担率}

図 18 にSTEP4 における試験体 No. 1 および試験体 No. 2 の各載荷段 階の沈下量と杭の荷重分担率の関係を示す。図から、初期の載荷段 階では両者ともに約 $83 \%$ 程度の荷重分担率であるが、試験体 No1 の 荷重分担率は載荷荷重の増加ならびに沈下量の増加に伴い杭の荷重 分担率は約 $90 \%$ まで上昇し、沈下量が $1.75 \mathrm{~mm}$ 程度以降から荷重分 担率は約 $86 \%$ 程度の一定值を示した。一方、試験体 No. 2 は沈下量 が $1 \mathrm{~mm}$ 程度までが約 $87 \%$ の荷重分担率を示し、以降は約 $84 \%$ 程度の 一定值を示した。

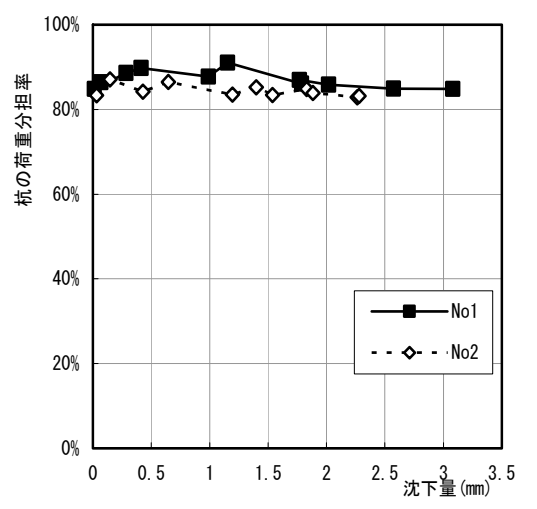

図 18 沈下量と杭の荷重分担率の関係

\section{5. 実験のまとめと考察}

今回の実大実験はテーパー杭を用いた基礎工法としてのパイルド ラフト効果について、沈下抑制効果および基礎スラブと杭の荷重分 担についての研究を目的として行なったものである。試験結果から 以下のように考察できる。

\section{a）荷重沈下関係}

(1) 載荷直後の沈下についてはテーパー杭を用いた試験体 No. 1 が最も小さな数值を示している。

このことは主にテーパー効果による支持力の優位性によるもの と推察できる。また STEP1の沈下と経過日数の関係からは、試験体 No. 1 ならびに No. 2 については、基礎スラブの硬化に従い基礎自重 が杭へ伝達し、その荷重による杭の沈下が生じたと思われる。

(2) 長期載荷試験の結果からテーパー杭を用いた試験体 No. 1 は
ストレート杭による試験体 No2 に比べ最終沈下量は約 $2 / 3$ に なり、沈下抑制効果に優位性が見られた。また、各試験体の 沈下量の比較では試験体 No. $1<$ 試験体 No. $2<$ 試験体 No. 3 の 順で大きな沈下量を示寸結果となった。

(3) 急速載荷試験の結果からテーパー杭を用いた試験体 No. 1 と ストレート杭による試験体 No2 とは同等な值となり、試験体 No. 3 が最も低い值を示す結果となった。

長期載荷試験の結果は、単に筆者らの研究 ${ }^{112)}$ により確認したテ ーパー杭の支持力に関する優位性だけではなく、基礎底面の反力お よびテーパー杭に生じる反力により沈下抑制効果が向上したと思 われる。

\section{b）杭の軸力分布及び摩擦応力}

(1) 図 11、図 12 に示寸ように STEP2、STEP3 の載荷直後の軸力分 布ならびに図 17 に示寸ように STEP4 での各載荷段階での軸 力分布は、いずれもテーパー杭がストレート杭に比べ、杭頭 部では大きな軸力を、杭先端部では小さな軸力となった。

(2) 図 13、図 14 に示すように杭の摩擦応力 $\tau$ についてもテーパ 一杭がストレート杭に比べ大きな值となった。

上記(1)(2については、筆者らにより粘性土地盤においてはテーパ 一杭がストレート杭の約 1. 3〜2 倍程度の摩擦応力を示すこと 1) 2) がわかっているが、今回でも同様な傾向を示寸結果となった。

\section{c）杭の荷重分担率}

(1) 図 15 に示寸ように、長期の載荷試験では、テーパー杭がス トレート杭に比べ大きな割合を示す結果となった。また、ば らつきはあるものの、試験体の沈下の推移に伴い荷重分担率

も荷重分担率の変化がみられた。

杭の荷重分担率に関しては、試験体の沈下量が増加するに従い杭 の荷重分担率が増加する傾向があると思われる。また、載荷直後で は試験体の沈下が急激なことにより、基礎スラブ下の地盤の支持力 の荷重分担が大きく、その後杭の周面摩擦による支持力の発現によ り杭の荷重分担が増加し沈下量が減少する傾向があると思われる。

小規模建築物の沈下抑制効果のある基礎工法として、テーパー杭 を用いた工法の沈下抑制効果に関する優位性および経過日数に伴う 現象を確認することができた。今後に向けての課題は、テーパー杭 を用いた基礎のパイルドラフト効果に関するシミュレーション等が 必要と考える。

\section{参考文献}

1) 山本、佐藤、塩沢：「小規模建築物の地盤補強に用いる杭工法に関する検 証（その 4)」日本建築学会大会学術講演梗概集（中国）、pp453-454、2008 2）佐藤、塩沢、安達: 「小規模建築物の地盤補強に用いる杭工法に関寸る検 証（その 5) 」日本建築学会大会学術講演梗概集（東北）、pp619-620、2009 3）冨永、陳、田村、若井：「圧入工法で施工された鋼管テーパー杭の各種現 場実験」, 日本建築学会技術報告集 第 13 巻 第 26 号, pp487-490

4）田村昌仁「戸建住宅の基礎地盤を考える」（財）佐賀県土木建築技術協会 平成 15 年度技術研修会テキスト P 25

[2009 年 10 月 21 日原稿受理 2009 年 12 月 4 日採用決定］ 